\title{
REASONS FOR CHOOSING ARABIC LANGUAGE AS A THIRD LANGUAGE: A CASE STUDY IN UITM PERAK
}

\author{
${ }^{1 *}$ Muhammad Anas Al-Muhsin, ${ }^{1}$ Khairun Nisaa Mohd, ${ }^{1}$ Nur Syafiqah Subri, ${ }^{1}$ Nurul Afifa Ishak \\ Faculty of Languages and Communication, Universiti Pendidikan Sultan Idris, Malaysia ${ }^{1}$ \\ Corresponding email: anas@fbk.upsi.edu.my
}

\begin{abstract}
With the increasing demand for Arabic courses in universities in Malaysia, it shows that students has their own reasons for choosing Arabic Language to study. The Arabic as a third language course is an elective subject offered to undergraduate students in UiTM. Starting from June 1999, UiTM has decided that third language courses should become one of the university's requirement subjects, making it compulsory to all first degree students. The purpose of this study was to identify the reasons of UiTM students for choosing to study Arabic Language as their third language. The sampling involves 320 students from UiTM, who have enrolled in level 1,2 and 3 Arabic course. This quantitative field research employs questionnaires and purposive sampling technique as the methods of data collection. The main findings are: most of them choose to learn Arabic language because it is the language of Islam and for them to understand more about Islam and also for worshipping purpose. Besides, most of them choose to learn the language for the purpose of their future career.
\end{abstract}

Keywords: Reasons, Arabic Language, Third Language.

Article Received: 18 October 2020, Revised: 3 November 2020, Accepted: 24 December 2020

\section{Introduction}

In the constitution of Malaysia, Malay language is being recognized as the national language of the country, meanwhile English language gains the recognition as the second language. Other languages that are learned and taught in Malaysia such as Arabic, Mandarin, Japanese, German, and Spanish were recognized as third language. In fact, foreign languages such as Arabic, Japanese, French, and German languages were introduced in the national secondary schools as part of the 1996 Education Act (See Soo Yin, Ching Thing Ho. 2007). Second language and foreign language are different from each other, and each of the languages have their own significant according to countries for example, English language is commonly learnt as the second language in most countries because of its more extensive usage in the international level, but it is only learnt as a foreign language in countries like Japan and France.

Looking at the situation in most universities in Malaysia the establishment of language centers or language units has managed to address the issue of language proficiency particularly in English Language among undergraduates (Raman Kutty, Gurusamy, Mahadir Naidu \& Vengadasalam, 2019; Gurusamy \& Thambu, 2018; Ganaprakasam, 2018). Language courses that are offered by each universities are different in terms of objectives and entities. Programmes in Languages, Linguistics and Literature started and evolved in various ways in different universities (Shanmugam, K., \& Balakrishnan, B., 2019: Shanmugam, K., \& Balakrishnan, B., 2020). Future Direction of Language Education in Malaysia. (2010).

Meanwhile Arabic Language were taught as a third language in UiTM starting from June 1999. This subject offered as an elective subject for undergraduate degree students. This means that students need to choose one of the third language courses offered and complete it before their graduation. Two hours is allocated for Arabic language classes every week. Cumulatively, within three semesters of the course, the students 
will have six credit hours and this equals to approximately 84 hours of meeting, with 28 hours of meeting in every semester (Yusri, G et al., 2012). Each of the students had different backgrounds in learning Arabic, some of them had years of experience in learning Arabic at school or another places, while others did not have any experiences at all. All these students were combined in the same classroom consisting of mixed abilities and experienced learners (Ghazali Yusri, Nik Mohd Rahimi, et al., 2011).

Therefore, this study is intended to investigate the reasons for them to choose Arabic Language to be studied. Besides, it also aims to find out what are the factors that motivates them to study Arabic. Another words for motivation is interest. Definition of motivation in language learning is "the dynamically changing cumulative arousal in a person that initiates, directs, coordinates, amplifies, terminates, and evaluates the cognitive and motor processes whereby initial wishes and desires are selected, prioritized, operationalized and (successfully or unsuccessfully) acted out" (Dornyei \& Otto, 1998). Another definition by Crookes and Schmidt (1991) motivation involves interest, relevance, expectancy of success or failure, belief in forthcoming rewards, decision to be involved, persistence, high activity level. Motivation is important in the beginning of language learning because it determines the students' preferences towards the choice of language, the way of language learning and the types of activities they preferred (Muhammad Anas Al Muhsin., \& Nor Zahidah Ahmad, 2019; Ahmad \& Al Muhsin, 2019).

\section{Objective of the study}

Investigating the students' reasons for choosing Arabic Language as a third language.

\section{Research question}

What are the main reasons for students to choose Arabic as a third language?

\section{Literature Review}

Arabic Language has a great impact on other world languages. If we look to the history of Arabic Language it is a symbol of a key of success for education during Islamic civilization. Nowadays, people around the world start to study Arabic language and intend to continue their learning of the language to a higher level. Proficiency in the Arabic language and exposure of the culture may equip students for professional opportunities, which can be found in education, international business, law, nursing, social work, government and armed forces. Thus, Arabic language arguably has a great impact on education and other languages around the world.

There are many reasons that motivates students to study Arabic. According to the research that were conducted by Che Mat \& Ying Soon the main objectives of learning Arabic language in Malaysia is because it is the language of Islam. Malaysia was known as a multiracial country and the economic situation in Malaysia was grown up day by day. Employment situation in Malaysia required from graduates to acquire various skills including proficiency in a third language in order to compete in this challenging world. Mastering a second or a third language provide the opportunity for the learners to acquire and secure a better prospect of career (Mohamed Safeer, M. U., \& Mohamed Nawastheen, F., 2019; M.I.M. Jazeel, M.B. Fowzul, \& A.R.F. Rakeeza., 2020). Employers nowadays seek for a multi-talented prospective employee, aces in many areas especially languages as this may help in increasing the performance of their department. Path for career enhancement may open wide for an employee who master more than one language as it fit the needs of the ever-evolving business markets and career prospects, which may require them to interact with global client and trade internationally. Robert Gardner (1985) argues in his research that the learners' reasons for learning second or third language is due to their instrumental motivation, which refers to their functional reason of learning is being driven by their desire of obtaining good jobs or higher salary or passing the examination. This is also being 
agreed by educational leaders around the world, as they consistently emphasizing the importance of fostering foreign language competency among the students.

Many researcher have found that there is strong relationship between the learner's motivation and reasons for them to choose Arabic as a third language. Most of students are also influenced by intrinsic and extrinsic motivations (Mottan, 2019: Maniam \& Vaithinathan, 2018; Ramasamy, Krishnan, \& Tee , 2020). Intrinsic motivation is when you do something because you enjoy it or find it interesting. While extrinsic motivation is doing something for external rewards or to avoid negative consequences. Most of students learnt a foreign language for extrinsic reasons such as for their future career, to equip them to become a more knowledgeable person or to fulfill the graduation requirement. Meanwhile for intrinsic reasons because they wanted to meet people of different cultures and languages, participated in their activities and enjoyed the foreign language learning experience (Zubairi, Sarudin, 2009). There are also findings that show Arabic language is very popular among Malay students for two reasons. First, because they wanted to understand Al-Qur'an because Arabic is the language of holy Qur'an. Second, a vast opportunities for employment has been opened up due to a significant surge in direct investments from in the Middle East. Subsequently, after the $11^{\text {th }}$ September incident, the influx of thousands of tourists from the Middle East has created necessities for graduates to equip themselves with knowledge of Arabic in all sectors related to tourism (Zubairi, Sarudin, 2009).

The reasons of learning Arabic language as the third language could also be sparked by the learners' interest on the Arab culture. The better way of understanding a culture is through mastering its language. The culture of a race is mostly reflected in their language, as it is the root to the establishment of custom and tradition of a culture. Learning language such as Arabic language provides access to the learners to comprehend the beauty of cultural representation through the spoken or written material related to it. Language users may utilize language to identify themselves and their societal status as well as their values, belief and attitudes when they talk. For instance, certain languages encode societal status in the grammar of the language. Language take up the role as a mean of communicating values, customs and beliefs, which possesses valuable social function and fosters group identity and solidarity. It is also one of the means by which culture and its traditions along with it shared values may be conveyed and preserved (Anak Osup, 2017; Arumugam, Kway \& Mohamed Isa, 2019; Hassan \& Thambu, 2018). Thus, the learners of the language may feel connected with the culture and tradition, where the language belongs to. Language enables individuals to pass on the rule of group behavior to each other and from one generation to another.

\section{Methodology}

\subsection{Participants}

About 320 students who studied Arabic Language as a third language in UiTM Seri Iskandar, Perak participated in the study.

\subsection{Data Collection and Analysis}

The nature of this study is by employing analytical descriptive approach in presenting and analyzing data that obtained from a survey that distributed to 320 students who studied Arabic Language as a third language in UiTM Seri Iskandar, Perak. Most of the participants were currently in their first and second semester of Arabic Studies. Therefore, 33 online questionnaire items corresponding various reasons were created, and distributed to the participants. The questionnaire consisted of 30 statements which required the students to respond to the items by simply evaluating a statement based on a fourpoint scale. In addition, three open - ended questions were added to give the opportunity to the students to include their own ideas on reasons for choosing Arabic as a third language. The questionnaire also sought to obtain the demographic information about the students. 
6. Analysis of Data

\subsection{Demographic Background}

Table 1: Gender

\begin{tabular}{|l|l|l|}
\hline Gender & Male & Female \\
\hline Percentage & $36.9 \%$ & $63.1 \%$ \\
\hline
\end{tabular}

The total number of participants were 202 $(63.1 \%)$ were female, while the male is 118 (36.9\%). Thus in this study the number of female participants was greater than male.

Table 2: Age

\begin{tabular}{|l|l|}
\hline Age & Percentage \\
\hline 18 & $12.8 \%$ \\
\hline 19 & $10.3 \%$ \\
\hline 20 & $1.9 \%$ \\
\hline 21 & $49.7 \%$ \\
\hline 22 & $19.7 \%$ \\
\hline 23 & $4.7 \%$ \\
\hline
\end{tabular}

\begin{tabular}{|l|l|}
\hline 24 and above & $0.9 \%$ \\
\hline
\end{tabular}

41 students $(12.8 \%)$ from age of 18, 33 of them (10.3\%) from age of 19, 6 of them (1.9\%) from age of 20, $159(49.7 \%)$ from age of 21. 63 $(19.7 \%)$ from age of $22.15(4.7 \%)$ of them from age of 23 . And $3(0.9 \%)$ of them from the age of 24 and above.

Table 3: Background in Arabic

\begin{tabular}{|l|l|}
\hline Background in Arabic & Percentage \\
\hline Yes & $79.4 \%$ \\
\hline No & $20.6 \%$ \\
\hline
\end{tabular}

$254(79.4 \%)$ of the participants stated that they had acquired the study of Arabic Language before they enter the university. While 66 (20.6\%) of the participants do not have any background in Arabic Language before joining the university.

Table 4: Interest

\begin{tabular}{|l|l|l|l|l|l|}
\hline & INTEREST & 1 & 2 & 3 & 4 \\
\hline 1 & I honestly really like to learn the Arabic language. & $1.9 \%$ & $4.4 \%$ & $58.9 \%$ & $34.8 \%$ \\
\hline 2 & $\begin{array}{l}\text { I like to learn the Arabic language because it is an } \\
\text { enjoyable experience. }\end{array}$ & $1.3 \%$ & $2.8 \%$ & $64.7 \%$ & $31.3 \%$ \\
\hline 3 & $\begin{array}{l}\text { I want to learn the Arabic language to know the } \\
\text { culture of Arab people. }\end{array}$ & $2.8 \%$ & $22.5 \%$ & $57.2 \%$ & $17.5 \%$ \\
\hline 4 & $\begin{array}{l}\text { I want to be able to use Arabic with Arab speaking } \\
\text { friends from overseas. }\end{array}$ & $2.2 \%$ & $10.3 \%$ & $33.4 \%$ & $54.1 \%$ \\
\hline 5 & $\begin{array}{l}\text { I want to be able to understand and appreciate } \\
\text { Arabic art and literature. }\end{array}$ & $1.3 \%$ & $4.7 \%$ & $32.7 \%$ & $61.3 \%$ \\
\hline
\end{tabular}

This study examined the reasons for UITM students to learn Arabic Language as their third language. Firstly, it is interesting to know that UITM students were highly motivated to learn Arabic Language because of some own reasons. The data tabulated in table 4 indicate the reasons of UITM students to learn Arabic language from the perspectives of personal interest. In general, most of them show a high interest in learning Arabic language. As shown in the table, most of the students $(64.7 \%)$ want to learn Arabic Language because it is an enjoyable experience. Meanwhile, they also show a high interest $(61.3 \%)$ on the point that they want to be able to understand and appreciate Arabic art and literature.

Table 5: Arabic Languages and Islam

\begin{tabular}{|l|l|l|l|l|l|}
\hline & ISLAMIC KNOWLEDGES & $\mathbf{1}$ & $\mathbf{2}$ & $\mathbf{3}$ & $\mathbf{4}$ \\
\hline 6 & $\begin{array}{l}\text { I want to learn Arabic because it is the language of t } \\
\text { Islamic religion. }\end{array}$ & $0.9 \%$ & $35.3 \%$ & $62.8 \%$ \\
\hline
\end{tabular}




\begin{tabular}{|c|l|l|l|l|l|}
\hline 7 & $\begin{array}{l}\text { I like to learn Arabic because I want to understand the f } 0.9 \% \\
\text { Quran and Hadith. }\end{array}$ & $0 \%$ & $30.3 \%$ & $68.8 \%$ \\
\hline 8 & $\begin{array}{l}\text { I want to learn Arabic because I want to understand t } \\
\text { meaning of my prayers (dua'). }\end{array}$ & $0.6 \%$ & $32.5 \%$ & $66.9 \%$ \\
\hline 9 & $\begin{array}{l}\text { I want to learn Arabic to increase the focus (khusyu') in n } \\
\text { daily worship (ibadah). }\end{array}$ & $0.9 \%$ & $1.3 \%$ & $37.8 \%$ & $60 \%$ \\
\hline 10 & $\begin{array}{l}\text { I like to learn Arabic to understand Arabic or Islan } \\
\text { programmes on mass media. }\end{array}$ & $0.9 \%$ & $8.1 \%$ & $30.3 \%$ & $60.6 \%$ \\
\hline
\end{tabular}

From this study, it also discovered that Arabic language is very popular among the student especially Malay students because this language related to Islam. All the respondents are Muslim and they have been exposed to the importance of Arabic through their religious rituals such as prayers and reciting Al-Quran. It is good to know that they wanted to learn Arabic because they want to understand the meaning of their prayers (dua') and also Al-Quran and Hadith that were written in Arabic. In addition the importance of language to them might be due to the respondents' religion, which is Islam. They want to learn Arabic because it is the language of the Islam. They also tend to study Arabic to increase their focus (khusyu') in daily worship (ibadah). And the last point which is to learn Arabic to understand Arabic or Islamic programmes on mass media get the lowest rate from students which seems not so important to them.

Table 6: Career

\begin{tabular}{|l|l|l|l|l|l|}
\hline & CAREER & 1 & 2 & 3 & 4 \\
\hline 11 & I will need the Arabic language for my future career. & $1.6 \%$ & $13.4 \%$ & $65.3 \%$ & $19.7 \%$ \\
\hline 12 & $\begin{array}{l}\text { I would like to work in the Middle East once I finish } \\
\text { my university studies. }\end{array}$ & $3.4 \%$ & $30.7 \%$ & $50.8 \%$ & $15 \%$ \\
\hline 13 & $\begin{array}{l}\text { I want to learn Arabic due to its commercial value } \\
\text { and extensive use. }\end{array}$ & $1.6 \%$ & $16.9 \%$ & $64.9 \%$ & $16.6 \%$ \\
\hline 14 & $\begin{array}{l}\text { I love to learn Arabic because it will make me a more } \\
\text { knowledgeable person. }\end{array}$ & $0.6 \%$ & $2.2 \%$ & $36.2 \%$ & $61 \%$ \\
\hline 15 & $\begin{array}{l}\text { I believe that people will think highly of me if I can } \\
\text { use Arabic in my future career. }\end{array}$ & $0.9 \%$ & $10.7 \%$ & $60.2 \%$ & $28.2 \%$ \\
\hline
\end{tabular}

Based on the data collected above, it shows that most of them $(65.3 \%)$ learn a foreign language because of their future career. Furthermore, $64.9 \%$ of them also agree that Arabic language is important to be learned due to its commercial value and extensive use. By learning this language, $61 \%$ of them agreed that they will become more knowledgeable and people will respect them. Besides, they $(60.2 \%)$ agree that they need it for their future career. Lastly, we notified that about half of them $(50.8 \%)$ prefer to work in the Middle East once they finish their university studies.
As for the finding from future plan perspective, $68.3 \%$ of the students said the important of mastering Arabic language is for the economic development of the world. Meanwhile, $56.7 \%$ of them were agreed that they wanted to go to Middle East to help people over there. It is also interesting to know that students chose to learn Arabic to read the literature of the Arabs in the original Arabic language. Furthermore, $54.7 \%$ of the student claimed to use Arabic language when they travel to an Arab-speaking country. 


\begin{tabular}{|c|l|l|l|l|l|}
\hline & FUTURE PLAN & 1 & 2 & 3 & 4 \\
\hline 16. & $\begin{array}{l}\text { I want to be able to use Arabic when I travel to an } \\
\text { Arab-speaking country. }\end{array}$ & $0.6 \%$ & $1.3 \%$ & $54.7 \%$ & $43.4 \%$ \\
\hline 17. & $\begin{array}{l}\text { I need to learn Arabic because I plan to further my } \\
\text { studies in the Middle East. }\end{array}$ & $4.7 \%$ & $38.1 \%$ & $45 \%$ & $12.3 \%$ \\
\hline 18. & $\begin{array}{l}\text { I want to read the literature of the Arabs in their } \\
\text { original Arabic language. }\end{array}$ & $1.9 \%$ & $20.1 \%$ & $56.4 \%$ & $21.6 \%$ \\
\hline 19. & $\begin{array}{l}\text { I feel that Arabic is important for the economic } \\
\text { development of the world. }\end{array}$ & $0.6 \%$ & $10.7 \%$ & $68.3 \%$ & $20.4 \%$ \\
\hline 20. & $\begin{array}{l}\text { I need Arabic because I want to go to the Middle } \\
\text { East to help people over there. }\end{array}$ & $2.2 \%$ & $21 \%$ & $20.1 \%$ & $\begin{array}{l}56 . \\
7 \%\end{array}$ \\
\hline
\end{tabular}

Table 8: Other Reasons for Choosing the Arabic Language

\begin{tabular}{|l|l|l|l|l|l|}
\hline & OTHERS & 1 & 2 & 3 & 4 \\
\hline 21 & $\begin{array}{l}\text { I need to study a foreign language for my degree, so } \\
\text { I just chose Arabic. }\end{array}$ & $1.6 \%$ & $16.4 \%$ & $61.3 \%$ & $20.8 \%$ \\
\hline 22 & $\begin{array}{l}\text { I feel that my teachers back in school encouraged } \\
\text { me to learn Arabic. }\end{array}$ & $3.8 \%$ & $26.3 \%$ & $51.4 \%$ & $18.5 \%$ \\
\hline 23 & $\begin{array}{l}\text { I feel that my friends back in school encouraged me } \\
\text { to learn Arabic. }\end{array}$ & $4.7 \%$ & $34.3 \%$ & $46.2 \%$ & $14.8 \%$ \\
\hline 24 & $\begin{array}{l}\text { I feel that my family members actually encouraged } \\
\text { me to learn Arabic. }\end{array}$ & $3.1 \%$ & $21.3 \%$ & $53 \%$ & $22.6 \%$ \\
\hline 25 & $\begin{array}{l}\text { I actually enjoy meeting and listening to Malay } \\
\text { people who can speak Arabic. }\end{array}$ & $0.6 \%$ & $6.3 \%$ & $65.2 \%$ & $27.9 \%$ \\
\hline 26 & $\begin{array}{l}\text { I think Malay people who can speak Arabic sound } \\
\text { quite religious. }\end{array}$ & $1.6 \%$ & $13.8 \%$ & $55.5 \%$ & $29.2 \%$ \\
\hline 27 & $\begin{array}{l}\text { I feel that Malay people who can speak Arabic are } \\
\text { quite honest people. }\end{array}$ & $2.2 \%$ & $29.8 \%$ & $53 \%$ & $15 \%$ \\
\hline 28 & $\begin{array}{l}\text { I think that compared to French, German or } \\
\text { Mandarin, Arabic is the best language to learn. }\end{array}$ & $1.9 \%$ & $11 \%$ & $58.6 \%$ & $28.5 \%$ \\
\hline 29. & $\begin{array}{l}\text { I feel that for my future career, Arabic will actually } \\
\text { be more important than my English. }\end{array}$ & $5.6 \%$ & $35.4 \%$ & $45.8 \%$ & $13.2 \%$ \\
\hline 30. & $\begin{array}{l}\text { I think that in Malaysia, we should promote Arabic } \\
\text { language as the most important third language to } \\
\text { learn. }\end{array}$ & $0.3 \%$ & $6.6 \%$ & $67 \%$ & $26.1 \%$ \\
\hline
\end{tabular}

Table 8 shows the other reasons for choosing the Arabic Language as a third language among the students. According to the result, among the main factors that motivate the respondents to choose Arabic language as foreign language course, most of them claimed that; Arabic language should be promote as the most important third language to be learn in Malaysia, they enjoy meeting and listening to Malay people who can speak Arabic and many of them agreed that they need to study a foreign language as part of the requirement for their degree.

In addition, most of them (58.6\%) agreed that Arabic is the best language to learn compared to French, German or Mandarin. The selection of a foreign language among the students is very much influenced by the characteristics of the language. As we know that Arabic is the language of Islam 
and because of that they also agree that people who can speak Arabic sound quite religious. Some of them also prefer to choose Arabic because it is a requirement from university.

\section{PART 3: OPEN ENDED QUESTION}

This analysis also supported by three open ended questions. The first question related to other reasons for choosing Arabic as a third language at university level. Firstly, the analysis found that the students' preference over a foreign language is based on the advantages the language has, which is beneficial and profitable for them. Most of them have an experience in learning Arabic before, thus, by taking this subject will make them easier to score in this subject, besides to recall back what they have learnt before. Secondly, the importance of the language to them might be due to the respondents' religion which is Islam. All the respondents are Muslims and they preferred this language to understand more about Islam for example to understand Al-Qur'an and Al-Hadith. They also claimed that Arabic Language is an interesting language to learn. They also state that they have to learn Arabic because the university did not give any other choices.

Meanwhile for the second question in this part, most of them answered the same like they have mentioned before which is because it is the language of Islam. They preferred to learn Arabic to understand the meaning of prayers (dua'), AlQur'an and Al-Hadith. Besides, the cultural factor in Malaysia which frequently use this language in media and daily activities also affected the students to choose Arabic. Islam has been identified as the main reasons for them to choose Arabic (Kaseh, Nik Farakh, \& Zeti Akhtar, 2010). The second factor was related to encouragement from family, lecturers and friends. Some of them claimed that they want to learn Arabic because of their parents. They encouraged them to learn Arabic because it is the language of Islam and they want their children to become a better Muslim. In addition, they also claimed that learning Arabic is exciting and their lecturer told them the importance of Arabic Language.
Moreover, they also claimed that it will be useful for their future career.

And the last question regarding additional things to add when learning Arabic Language as a third language, we found that they did not suggest many ideas. Some of them also suggested to improve the way of teaching by using additional teaching materials such as visual, audio, slides and also interactive activities such as games and songs. Other suggestion that has been proposed by them is by improving the textbook that have been used for example to include words with meanings (Malay words), grammar and example of sentences from Al-Qur'an. Furthermore, some of them also suggest to provide an Arabic Language Learning Center that is free for student. Thus, it can give more opportunity for the students to learn Arabic language. Lastly, they preferred to learn in an environment with a few students inside the class so that the lecturer can focus more on weaker students.

\section{Results and Discussions}

In conclusion the main reasons for UiTM students' to learn Arabic as their third language is because of religion, culture and language status in the Malay community. From this research, all the respondents are Muslims and as a Muslim they have been exposed to the importance of Arabic through their religious rituals, such as reciting alQuran, al-Hadith and prayers. Besides, the cultural factor in Malaysia especially among the Malay Muslim community, which uses this language very frequently in daily activities, might also familiarise the community with Arabic language. Moreover, some of the Malay words such as 'Solat', 'Zakat' and 'Wakaf' are borrowed from the Arabic language. Islam was playing a role as the main motivation in learning Arabic (Kaseh, Nik Farakh, \& Zeti Akhtar, 2010). In addition the learners also agree that by learning Arabic, they will receive benefits in terms of becoming a more knowledgeable person and because of that they could secure a good job or give them the opportunity to achieve their aims and objectives in their future careers. They also can use this 
language when they travel to Arab-speaking countries.

Besides, the encouragement from family, lecturers and friends also play a role in motivating them to choose Arabic. Some of them who had an experience learning Arabic before in schools also find the course to be simple and pleasantry since they find it convenient as the learning experience may be almost similar with what they might have gone through in their previous Arabic schools. This paper, therefore suggests that the undergraduate Arabic curriculum in UiTM should be reexamined and redesigned from time to time according to students' need. Educators in Arabic Language also should be creative as we are living in the $21^{\text {st }}$ century era where education system also be influenced by Industrial Revolution 4.0 (IR 4.0) and now it was known as education 4.0. "Education 4.0" is the responds to the needs of "industry 4.0" where man and machine align to enable new possibilities (Hussin, 2018). Therefore, learning process should be creative, innovative and interactive and most importantly responsive to students' needs. Learning foreign language is not easy or easy as well. It depends on students' age and the environment in which they live during the learning of the language, but we can make the language learning interesting and easy to learn through research and study (Mufleh, 2013). There are number of ways to teach the language in a short time and a reasonable effort. Education 4.0 produce nine trends in learning strategies (Fisk, 2017).

1- Learning process can be taken at anytime and anywhere as technologies nowadays offered e-learning tools. Flipped classroom approach also can be practice as it allows interactive learning to be done in class, while the theoretical parts to be learned outside the class time.

2- Learning process should be focus more on individual students. They need to follow the step where the harder tasks only come after they achieved the mastery level. More practices will be given if the instructors see a need in it. In this step, positive reinforcements will be use to promote positive learning experience and boost students' confidence about their own academic abilities.

3- Students have a freedom in determining the way they want to learn. The institutions who in charge of the curriculum will give a freedom to students to choose the learning tools or techniques that they prefer. Among the options that lecturers can adopt to enable students to be creative in their learning are blended learning, flipped classroom and BYOD (Bring Your Own Device) approach.

4- Students are needed to apply their knowledge and skills in completing a couple of short term projects. This is called as project-based learning. From this projects, they can practice organizational skills, collaborative among teammates and also time management skills which give them benefits for their future academic careers.

5- Students are needed to join themselves in learning through field experience such as internships, mentoring projects and collaborative projects.

6- Students will be introduce with data interpretation skills in which they are required to apply their theoretical knowledge to numbers and use their reasoning skills to make inferences based on logic and trends from given sets of data.

7- Students will be assessed in a different ways for example they can be accessed during the learning process, while the application of the knowledge can be tested when they are working on their projects in the field.

8- Students' opinion will be considered in designing the module and curriculum as their ideas and input will help the curriculum designers to maintain the contemporariness and usefulness.

9- Students will become more independent in their own learning process. 
From all these points, we can see that Education 4.0 change the major learning responsibilities from the instructors to the learners. Therefore, further research need to be done on how to develop an interactive Arabic language class in UiTM so that they will be motivated in learning Arabic.

\section{References}

[1] Ahmad, N. Z., \& Al Muhsin, M. A. (2019). Analisis keperluan bahasa arab untuk pegawai shariah di bank-bank islam di Malaysia: idea untuk pendidikan 4.0. Muallim Journal of Social Sciences and Humanities, 3(2), 246-257. https://doi.org/10.33306/mjssh18

[2] Ainol Madziah Zubairi, Isarji Haji Sarudin. (2009). Motivation To Learn A Foreign Language In Malaysia, GEMA Online Journal of Language Studies, 1 (2), 73-87.

[3] Anak Osup, C. (2017). Various types of instruments in the inventory of Iban cultural music. Muallim Journal of Social Sciences and Humanities, 1(2), 1-20. Retrieved from https://www.mjsshonline.com/index.php/jo urnal/article/view/7

[4] Ariff Mohammed Mufleh. (2013). Difficulties face by foreign students in learning arabic language programs for non-native speakers (Evaluation Study). Journal of Education and Practice, 22221735, 160-170.

[5] Arumugam, S., Kway, E. H., \& Mohamed Isa, Z. (2019). Methodology of developing symptomatic behavior screening tool (symbest) for children aged 3-4 years old with behavior problems. Muallim Journal of Social Sciences and Humanities, 3(3), 324-341. https://doi.org/10.33306/mjssh25

[6] Anealka Aziz Hussin. (2018). Education 4.0 Made Simple: Ideas For Teaching. International Journal of Education \& Literacy Studies, 2202-9478.
[7] Azman Che Mat, Goh Yin Sing, Situasi Pembelajaran Bahasa Asing di Institut Pengajian Tinggi: Perbandingan Antara Bahasa Arab, Bahasa Mandarin dan Bahasa Perancis, AJTHLE, 2 (2), 9-21.

[8] Crookes, G. \& Schmidt, R.W. (1991). Motivation: Reopening the research agenda.Language Learning, 41, 469-512.

[9] Dornyei, Z. \& Otto, I. (1998). Motivation in action: A process model of L2 motivation.Working papers in Applied linguistics (Thames Valley University, London), 4, 43-69.

[10] Fisk, P. (2017). Education 4.0 ... the future of learning will be dramatically different, in school and throughout life. Retrieved from

http://www.thegeniusworks.com/2017/01/futureeducationyoung-everyone-taught-together

[11] Ganaprakasam, C. (2018). Emotional intelligence on suicidal ideation and mental health. Muallim Journal of Social Sciences and Humanities, 2(3), 185-195. Retrieved from https://www.mjsshonline.com/index.php/jo urnal/article/view/62

[12] Ghazali Yusri, Nik Mohd Rahimi, Parilah M. Shah, Wan Haslina Wan Abd Halim. (2011). Attitudes towards Learning Oral Arabic among Students in Different Learning Environments, The International Journal - Language Society and Culture, 33, 27-34.

[13] Gurusamy, V., \& Thambu, N. (2018). Development of moral motivation through acting activities in teaching and learning of Moral Education in secondary schools [Perkembangan motivasi moral murid melalui aktiviti lakonan dalam pengajaran dan pembelajaran Pendidikan Moral di sekolah menengah]. Muallim Journal of Social Sciences and Humanities, 2(4), 234250. Retrieved from https://www.mjsshonline.com/index.php/jo urnal/article/view/70 
[14] Hassan, M. H., \& Thambu, N. (2018). Moral teachers' self-efficacy in secondary school: A pilot study [Efikasi kendiri guru pendidikan moral di sekolah menengah: Satu kajian rintis]. Muallim Journal of Social Sciences and Humanities, 2(3), 161$176 . \quad$ Retrieved from https://www.mjsshonline.com/index.php/jo urnal/article/view/60

[15] Kaseh Abu Bakar, Nik Farakh Sulaiman, \& Zeti Akhtar Mohd Rafaai (2010). SelfDetermination Theory and motivational orientations of Arabic learners: A principal component analysis. GEMA Online Journal of Language Studies, 10(1), 71-86.

[16] Maniam, M., \& Vaithinathan, K. (2018). Motivating ESL learners of low proficiency in reading through an extensive reading programme. Muallim Journal of Social Sciences and Humanities, 2(3), 177-184. Retrieved from https://www.mjsshonline.com/index.php/jo urnal/article/view/61

[17] M.I.M. Jazeel, M.B. Fowzul, \& A.R.F. Rakeeza. (2020). The judgements of Quazi Courts in Sri Lanka: An analysis. Muallim Journal of Social Sciences and Humanities, 4(1), $1-15$. https://doi.org/10.33306/mjssh/50

[18] Mohamed Safeer, M. U., \& Mohamed Nawastheen, F. (2019). Problems faced by graduate teachers who recruited without indicating their subject category in the Tamil medium schools in Eastern Province of Sri Lanka. Muallim Journal of Social Sciences and Humanities, 3(4), 379-397. https://doi.org/10.33306/mjssh/42

[19] Mottan, K. (2019). Impact of kineasthetic gamification on disruptive behaviour among children with attention deficit disorder/attention deficit hyperactive disorder (ADD/ADHD) in primary school learning disabilities programme. Muallim Journal of Social Sciences and Humanities, 3(4), 398-405. https://doi.org/10.33306/mjssh/30
[20] Muhammad Anas Al Muhsin., \& Nor Zahidah Ahmad. (2019). The emergence of education 4.0 trends in teaching Arabic Islamic finance curriculum design : A case study. International Jounal of Psychosocial Rehabilitation, 23(4),10191031.

[21] Raman Kutty, S., Gurusamy, V., Mahadir Naidu, N. B., \& Vengadasalam, C. (2019). The usage of schoology to describe issue in Moral education through flipped classroom [Penggunaan schoology untuk memerihalkan isu dalam pendidikan Moral menerusi kelas berbalik (flipped classroom)]. Muallim Journal of Social Sciences and Humanities, 3(3), 295-307. https://doi.org/10.33306/mjssh23

[22] Ramasamy, P., Krishnan, S., \& Tee, Y. L. (2020). General relationship between conformity and peers pressure among form 3 students of secondary school in Johor Bahru. Muallim Journal of Social Sciences and Humanities, 4(1), 16-28. https://doi.org/10.33306/mjssh/51

[23] Shanmugam, K., \& Balakrishnan, B. (2020). Microsoft power point as a presentation tool for teaching and facilitating science in rural Tamil schools in Perak [Perisian microsoft power point sebagai peranti persembahan semasa pdpc sains di $\operatorname{SJK}(\mathrm{T})$ luar bandar di negeri Perak]. Muallim Journal of Social Sciences and Humanities, 4(1), 49-65. https://doi.org/10.33306/mjssh/55

[24] Shanmugam, K., \& Balakrishnan, B. (2019). Designing an ICT guiding framework for science teachers in rural Tamil schools in Perak [Pembinaan kerangka panduan ICT bagi mata pelajaran sains untuk guru-guru $\mathrm{SJK}(\mathrm{T})$ di luar bandar di negeri Perak]. Muallim Journal of Social Sciences and Humanities, 3(4), 441-458.

\section{https://doi.org/10.33306/mjssh/34}

[25] See Soo Yin, Ching Thing Ho. (2013). Mandarin As The Chosen Foreign 
Language Course Among Learners Of Foreign Language: A Case Study, Journal of Arts, Science \& Commerce, 4, 3 (1), 8088.

[26] Yusri, G, Rahimi N. M, Shah P.M, Wan Haslina, W. (2012). Attitudes Towards Learning Oral Arabic as a Foreign Language among Malaysian Students. Pertanika J. Soc. Sci. \& Hum. 20 (3): 765780. 